This item was submitted to Loughborough's Research Repository by the author.

Items in Figshare are protected by copyright, with all rights reserved, unless otherwise indicated.

\title{
A politics of recognition and respect: involving people with experience of poverty in decision making that affects their lives
}

PLEASE CITE THE PUBLISHED VERSION

\section{PUBLISHER}

(c) Cambridge University Press

\section{LICENCE}

CC BY-NC-ND 4.0

\section{REPOSITORY RECORD}

Lister, Ruth. 2019. "A Politics of Recognition and Respect: Involving People with Experience of Poverty in Decision Making That Affects Their Lives”. figshare. https://hdl.handle.net/2134/2223. 
This item was submitted to Loughborough's Institutional Repository by the author and is made available under the following Creative Commons Licence conditions.

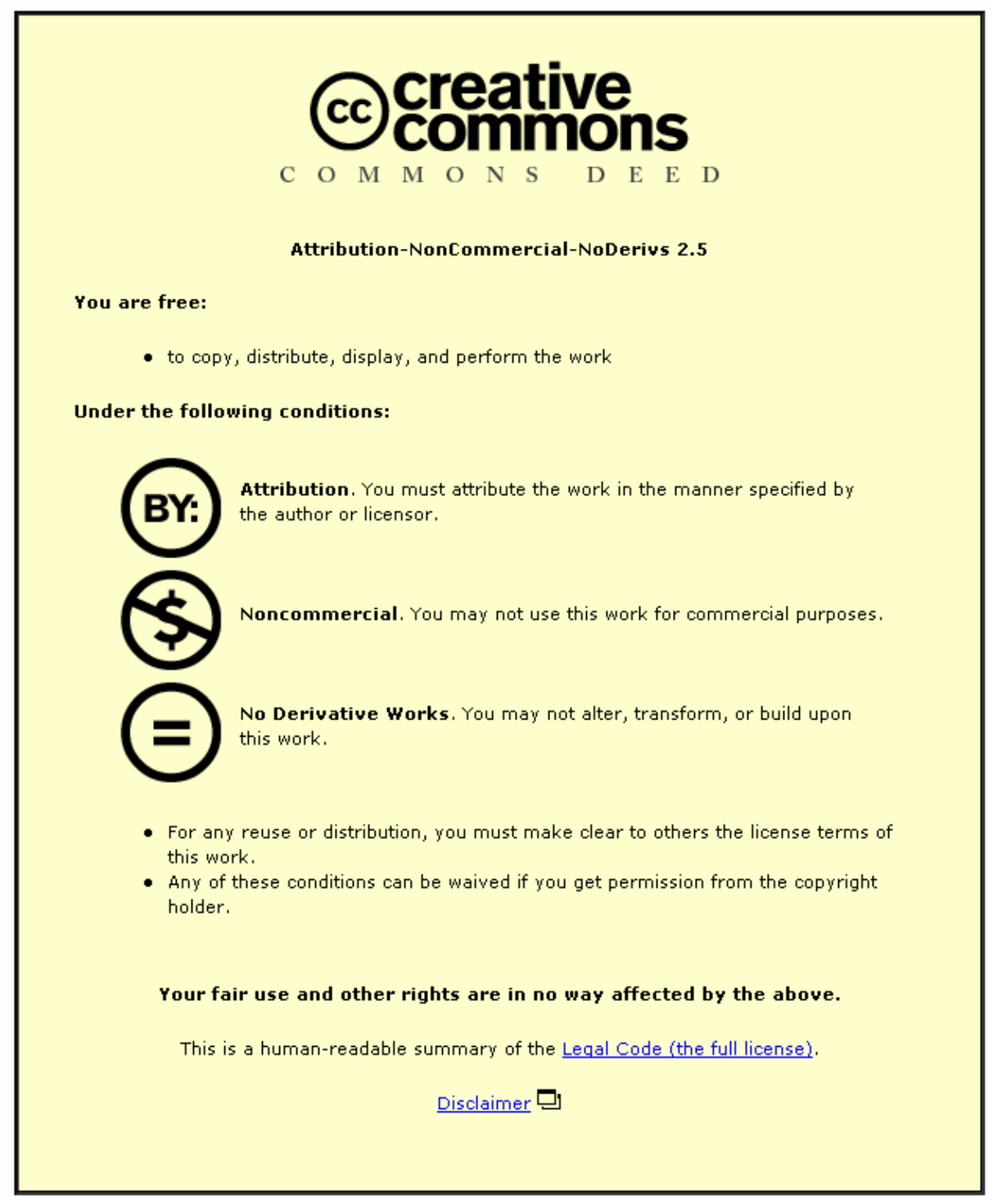

For the full text of this licence, please go to: http://creativecommons.org/licenses/by-nc-nd/2.5/ 


\title{
A Politics of Recognition and Respect: Involving People with Experience of Poverty in Decision making that Affects their Lives
}

\section{Ruth Lister}

Department of Social Sciences, University of Loughborough

E-mail:m.r.lister@lboro.ac.uk

\begin{abstract}
Introduction
People living in poverty and their organisations should be empowered by . . . encouraging and assisting [them] to organise . . . and . . . involving them fully in the setting of targets, and in the design, implementation, monitoring and assessment of national strategies and programmes for poverty eradication and community-based development . . The full participation of people living in poverty is a fundamental and equally obligatory part of the process.
\end{abstract}

In 1995, over 100 countries signed up to this statement in the Copenhagen Declaration and Programme of Action at the UN World Summit for Social Development. The second section of this article reflects on an initiative in the UK, which aims to make a reality of the Copenhagen commitment around the demand for the involvement of people in poverty in decision making that affects their lives. The first, longer, section makes a normative theoretical case for such action.

\section{Theoretical perspectives}

The politics of poverty is increasingly being couched in a non-materialist discourse of human and citizenship rights, democracy, inclusion and respect (see for example DfID, 2000; Bur, Stevens and Young, 1999; UNDP, 2000; ATD, 2000). It can be characterised as 'a politics of recognition and respect'. ${ }^{1}$ This does not necessarily represent a denial of the material conditions that lie at the heart of poverty. Rather it offers an opportunity to transform the politics of poverty into one that addresses questions of power as well as material resources. At the same time, it integrates the concerns of those in poverty into wider debates about citizenship and democracy, rather than treating them as separate. This section represents an initial attempt to develop an analytical framework in which this emergent politics of poverty can be both understood and forged. It does so through the application of a number of at times overlapping concepts in social and political theory.

\section{Social exclusion}

Social exclusion has become an increasingly fashionable concept in many parts of Europe, including New Labour's Britain. Graham Room (1995: 5) has suggested that, whereas the notion of poverty primarily concerns the distribution of material resources,

Shortened and updated version of a paper given at the GEP International Conference 'New Challenges to Gender, Democracy, Welfare States', Denmark, August 2000. 
that of social exclusion focuses 'primarily on relational issues, in other words, inadequate social participation, lack of social integration and lack of power'. The last element points to the political as well as social nature of exclusion.

In the same volume, Jos Berghman identifies as helpful the breadth and dynamic nature of the notion of social exclusion, conceptualised as 'the denial - or non-realisation - of citizenship rights', following the European Observatory on Policies to Combat Social Exclusion (Berghman, 1995: 19). The dynamic aspect of the concept encourages a shift of focus from outcomes to economic and political processes (Wilson, 1995; Byrne, 1999). A more dynamic approach also opens up space for the agency of those excluded as political and social actors, rather than treating them simply as passive victims (Deacon and Mann, 1999).

This conceptualisation of social exclusion is representative of what Ruth Levitas has dubbed RED, a redistributive, egalitarian discourse. As she notes, 'from the perspective of RED, political inclusion is an aspect of social inclusion' (Levitas, 1998: 173). However, such a discourse is less prominent in contemporary British and EU politics than those of SID (social integrationist discourse), which focuses mainly on the labour market, and, to a lesser extent, MUD (moral 'underclass' discourse). The growing demands to involve people in poverty in the decision making that affects their lives represents a challenge to a narrow conceptualisation of social exclusion, limited to labour market participation, and to a derogatory conceptualisation, which labels people in poverty as passive welfare 'dependants'.

\section{Citizenship}

Such demands draw, instead, implicitly on RED, which also represents an expansive discourse of citizenship, embracing civil, political, cultural and social rights. Citizenship is, in part, about equality of status and respect (relevant also to recognition politics, see below). The inclusion of people in poverty in poverty discussions has been described as 'part of the broader issue of addressing the restricted citizenship of people who are poor' (Beresford et al., 1999: 27).

In some strands of contemporary citizenship theory, drawing on both the (social) liberal and civic republican traditions, participation in decision making is put forward as a citizenship right. Thomas Janoski, for instance, makes the case for 'a right of participation', suggesting that its addition to the panoply of rights 'pushes citizenship rights into the center of more recent welfare state controversies and democratic struggles' (1998: 50).

The right to participation has also been promoted as a human and not just a citizenship right. Carol Gould (1988) has argued for an extension of the human right of democratic participation to include the right of participation in social and economic decision making. Her argument is grounded in the agency of human beings and in the principle of freedom as self-development.

In some cases, citizenship and human rights discourses are combined to make the case for the involvement of people in poverty in decisions that affect their lives. In a consultation document the British Department for International Development (DfID) argues that human rights 'provide a means of empowering all people to make decisions about their own lives rather than being the passive objects of choices made on their behalf'. The document 'sets out the practical ways in which the human rights framework 
contributes to the achievement of the objective of enabling all people to be active citizens with rights, expectations and responsibilities' (DfID, 2000: 1).

The experience of ATD Fourth World, which works with severely disadvantaged people to promote their effective social and political participation, demonstrates how the very process of participation helps to build self-esteem and thus strengthen the agency of people in poverty, thereby enabling them to act more effectively as citizens (ATD Fourth World, 1996, 2000). To act as a citizen requires a sense of agency, the belief that one can act; acting as a citizen, especially collectively, in turn fosters that sense of agency (Lister, 1997).

An example is provided by a British parliamentary initiative in which an All-Party Parliamentary Group (APPG) of Members of Parliament has involved, on a regular basis, people with experience of poverty in its meetings. In its first report, a typical observation from participants was that 'taking part in the APPG has helped me to learn what I can do to make differences, to know what I can contribute' (APPG on Poverty, 1999: 4). The report observes that the initiative 'extends democracy beyond the reach of the already powerful and allows the experts to speak for themselves, and often to significant effect'. It suggests that 'the humanisation of the democratic process is important for real participation and respectful exchanges to take place' (ibid.). Dialogues such as these represent the promotion of citizenship through greater democratic accountability (Cornwall and Gaventa, 2000).

\section{Democracy}

The invocation of principles of democracy addresses two concerns: the growing exclusion and detachment of those in poverty from the democratic process and dissatisfaction in some quarters with the practice of representative democracy. It also chimes in tune with some of the rhetoric of the 'third way'.

One of the most prominent critics of the political marginalisation of those in poverty has been Galbraith. In the US context, he has written of how the contented majority 'rule under the rich cloak of democracy, a democracy in which the less fortunate do not participate' (1992: 15). The solution, he suggests, 'is more active political participation by a coalition of the concerned and the poor' (1996: 141). Galbraith is here concerned with electoral politics. His argument is that the non-participation of people in poverty at the ballot box means that their interests and concerns are increasingly ignored by the political parties. The same phenomenon, albeit to a lesser extent, is increasingly true of Britain. Under the 'first past the post' electoral system, voters in safe seats, which include many of the poorest areas, can safely be ignored. Electoral politics are increasingly played out in a small number of marginal seats. Electoral turn-out in the deprived innercity areas is generally lower than average.

This is one of the arguments used in favour of electoral reform to achieve proportional representation. The political exclusion of those in poverty also raises questions about the very nature of modern democracy. Political theorists, such as Carol Gould (1988), have made the case for the democratisation of all the institutions of society - social, economic and cultural as well as political (see also Pateman, 1970).

Anthony Giddens, in his exposition of the third way, has argued for the 'democratization of democracy'. He contends that 'the crisis of democracy comes from its not being democratic enough' in the face of 'the demand for individual autonomy and the 
emergence of a more reflexive citizenry' (1998: 71; 2000). Echoing Giddens, Tony Blair has written of the third way's 'democratic impulse', which 'needs to be strengthened by finding new ways to enable citizens to share in decision making that affects them' (1998: 15). In an essay on phase two of the third way, he highlights 'renewing democracy' as a key challenge, acknowledging that 'democracy needs to respond to people's demand that they have a right to be listened to even if decisions do not always go the way they want' (Blair, 2001: 12).

The increased emphasis on more participatory democratic mechanisms is, though, raising questions about the relationship between participatory and representative democracy, especially at local government level. Some in local government have resisted more participatory forms of democracy on the grounds that they undermine representative democracy. Others have responded that 'an active conception of representative democracy can be reinforced by participatory democracy' (Clarke and Stewart, 1998: 3; see also Young, 2000).

Principles of deliberative and participatory democracy are one element in the case made for 'radical democracy' (Mouffe, 1992; Trend, 1996). The other key principle is that of radical pluralism. Central to the notion of deliberative democracy is the provision of public space in which the voices of different groups can be heard and can deliberate (Young, 1990). In her recent work, Iris Young has elaborated on the notion of 'social perspective' to reinforce her earlier arguments for mechanisms for the effective recognition and representation of disadvantaged groups, while avoiding attributing to such groups shared opinions or interests. 'Social perspective' is, she explains, 'the point of view group members have on social processes because of their position in them'; perspective reflects experience but does not determine what group members think or want (2000: 137). Democratic debate and decision making is, she maintains, strengthened, if it is informed by a wide range of perspectives, including, in particular, those of marginalised groups.

Nancy Fraser, likewise, defines radical democracy in terms of opposition to 'two very different kinds of impediments to democratic participation', namely social inequality and 'the misrecognition of difference. Radical democracy, on this interpretation is the view that democracy today requires both social equality and multicultural recognition' (1996: 198).

\section{Recognition}

While Fraser's concern is with the recognition and misrecognition of difference, as argued above, the demand for recognition is becoming more vocal in the politics of poverty also, as that politics is increasingly expressed as a politics of 'voice' (Yeatman, 1994; Williams, 1999). In her original intervention on the politics of redistribution and of recognition, Fraser (1995/97) roots the former in the struggle against socio-economic injustice and the latter in the struggle against cultural or symbolic injustice. Poverty is quintessentially the product of socio-economic injustice and anti-poverty campaigns are central to any politics of redistribution. At the same time, though, these campaigns increasingly deploy a discourse of recognition as well as of redistribution.

Charles Taylor (1992) has identified recognition as a vital human need and underlined the damaging impact of misrecognition on identity. This is reflected in the examples of cultural or symbolic injustice cited by Fraser: 
Nonrecognition (being rendered invisible via the authoritative representational, communicative, and interpretative practices of one's culture); and disrespect (being routinely maligned or disparaged in stereotypic public cultural representations and/or in everyday life interactions). (Fraser, 1995: 71/1997: 14)

Nonrecognition, misrecognition and disrespect are the typical experience of those in poverty, especially when labelled pejoratively as an 'underclass' or as inhabiting a 'dependency culture'. One consequence is that some are reluctant to identify themselves as 'poor'. At a National Poverty Hearing in London, one of the most common refrains among those with experience of poverty was the desire to be treated with greater respect. I just feel very angry sometimes that people are ignorant to the fact that we are humans as well and we do need to be respected' was typical of comments made (Russell, 1996: 10). David Donnison has suggested that the demand for respect and 'to be treated as the equal of anyone else' is indicative of an emergent new paradigm in social policy (2000: 25; see also Donnison, 1998). In an international context, the Human Development Report 200 identifies 'a life of respect and value' as a key aim of human development (UNDP, 2000: 2)

In her critique of Fraser, Young places greater emphasis on the interrelationship between economic and cultural injustice. She maintains that 'we should show how recognition is a means to, or an element in, economic and political equality and that 'so long as the cultural denigration of groups produces or reinforces structural economic oppressions, the two struggles are continuous' (Young, 1997: 156 and 159). In a more recent intervention, Fraser herself pays more attention to the interaction between the economic and cultural. The theoretical move that she makes is to treat misrecognition as a question of social status subordination and injustice, rather than of identity:

From this perspective, what requires recognition is not group-specific identity but the status of individual group members as full partners in social interaction . . . It means a politics aimed at overcoming subordination by establishing the misrecognized party as a full member of society capable of participating on a par with the rest. (2000: 113)

The obstacles to 'participatory parity' on this model are not just cultural but lie also in the maldistribution of resources. Although Fraser herself does not make the link, such an approach is highly relevant to the politics of poverty. Here a politics of recognition is not about the assertion of group difference, even if it is, in part, about 'positive group definition' (Young, 2000: 103). Indeed a successful politics of redistribution could remove the category altogether, as 'the poor' are a group who are primarily the product of the maldistribution of resources. A politics of recognition in this context is, instead, primarily about the assertion of recognition in the sense of equality of status and respect, which, as stated above, are critical to the recognition of the full citizenship of those in poverty.

It is also about recognition of and respect for the expertise borne of experience, which, using Young's (2000) framework, brings important and relevant perspectives to bear on decision making. ATD Fourth World rejects the common construction of people living in poverty as 'objects of other people's knowledge, not as authors of their own development - as problems' for 'they have something to offer, something to contribute' (1999: 16; see also Holman, 1998). What is at issue here is the value accorded to people in poverty's own interpretation of their needs and demands (Beresford and Croft, 1995; Lister and Beresford, 2000). Roberts, another participant in the National Poverty Hearing, argued: 
Ruth Lister

No-one asks our views . . We are the real experts of our own hopes and aspirations . . We can contribute if you are prepared to give up a little power to allow us to participate as partners in our own future. (Russell, 1996: 4)

Power and empowerment

Roberts points to a crucial element in the equation: that of power. As Levitas observes, theories of dialogic and deliberative democracy tend to underplay the importance of 'the structures of power' within which dialogue and deliberation take place' (Levitas, 1998: 176). Beresford and Croft suggest that 'it is poor people's powerlessness which lies at the heart of their exclusion from the poverty debate and helps to explain it' (1995: 79). If this powerlessness is not addressed, general strategies to promote participatory democracy could exacerbate rather than redress imbalances of power (Bur, Stevens and Young, 1999: 14).

The 1997 United Nations Human Development Report (1997) identifies 'the political empowerment of poor people' as an essential element in 'a political strategy for poverty'. Similarly, drawing on the work of Freire, Byrne looks to the collective 'empowerment of the dispossessed' as part of 'a popular democratic politics of solidarity' necessary to combat social exclusion (1999: 133).

The process of empowerment concerns two aspects of power. One is what Giddens (1991) calls 'generative' power, which is about 'self-actualisation'. Hartsock describes it as 'related to energy, capacity and potential' (1985: 210). It is this kind of power which is developed through the community development process of 'capacity-building' and which can be witnessed in the very process of participation, as confidence and selfesteem grow. However, feminists and others have warned against reducing empowerment to an individual social-psychological process, thereby losing sight of the importance of collective empowerment to achieve social change and to alter the distribution of power. Virginia Rinaldo Seitz thus defines empowerment as 'both a process and an outcome of collective identity and political praxis, resulting in a capacity in thought and action to address the condition and position of marginalization' (1998: 234).

Such transformatory understandings are to be distinguished from those more 'topdown' approaches that are about 'empowering' the powerless to adjust to the consequences of global economic restructuring (Mayo, 2001). The latter does nothing to disturb 'hierarchical' power relations, which enable a group or individual to exert their will over others (Giddens, 1991). This means that, ultimately, individual empowerment of a generative kind will need to lead to some redistribution of hierarchical power, if people in poverty are to achieve genuine empowerment through participation. This, in turn, raises more fundamental questions about the structural determinants of the poverty they experience (Phillips, 2001).

\section{Participation in practice}

The normative ideal for which the first part of this article has argued stands in contrast to the reality in Britain. As a recent participatory study with people in poverty observed 'one key group has been conspicuous by its absence so far in poverty discussion and policy development - people with experience of poverty themselves' (Beresford et al., 1999: 24). 
Increasingly, however, following the example of the disabled people's movement, demands are emerging for the voices of those in poverty to be heard directly rather than just filtered through the professional 'poverty lobby', which emerged during the 1960s and 1970s, in part because of the collective weakness of people in poverty as a political constituency. A number of initiatives and projects have acted as prefigurative models. One such project, in which I was involved, is described here. It is the Commission on Poverty, Participation and Power, which emerged out of a participatory consultation process conducted through the UK Coalition against Poverty's Voices for Change project.

Over a two-year period, the project worked from the local level, building up to area meetings and a UK-wide meeting. Much of the local work involved 'capacity building' and training as well as investigation into participation and the barriers to it. It used the technique of 'participatory appraisal (PA)', one of a family of participatory methods developed in the southern hemisphere, which has been borrowed as a community development tool to work with disadvantaged communities in the industrialised world. ${ }^{2}$ The technique involves marginalised people as active participants from the outset so that they can conduct their own consultations and train others.

The participatory origins of the Commission are one of the features that make it unusual, if not unique, although in practice it proved difficult to maintain links with that process, once the Commission's work began. The other is the Commission's composition: a mixture of 'people in public life' and 'grassroots' people with direct experience of poverty. This meant developing ways of working which are not typical of committees and Commissions. Thus, for example, participatory exercises were used to facilitate the sharing of ideas and the decision was taken at the first meeting not to appoint a formal chair who would immediately become 'first among equals'. Meetings were often very difficult, as people from very different backgrounds had to learn to work together. It was frequently impossible to keep to agendas, which did not provide the space for 'grassroots' Commissioners to express themselves in the ways that they wanted or to deal with issues arising in their lives. In the early stages, 'public life' Commissioners were sometimes challenged as to what they knew about poverty, a sobering experience for those normally treated as 'experts'.

Yet, for all the very real difficulties, there was always an incredible energy in what were pretty long meetings and much was achieved. Moreover, for some of the 'public life' Commissioners the experience has been transformative. As ATD $4^{\text {th }}$ World has observed, this kind of democratic process 'requires us all to be ready to change' (ATD, 1996: 61). Even though it required committing at a different, more emotional level, than is usual in committees, one of the most profound lessons for me was that, even so, I was not engaging at the level of the 'grassroots' Commissioners for whom much more was at stake. As one woman Commissioner said 'we've sold a lot of our souls some of us sitting round this table - it better be worth it'. If it is not 'worth it', the costs for 'public life' Commissioners will be relatively small, whereas they will be massive for 'grassroots' Commissioners, both personally and because of the expectations of people in the communities in which they are based. Thus, the boundaries between 'public' and 'private', between 'political' and 'personal' have been much more porous for 'grassroots' than 'public life' commissioners.

It quickly became clear from evidence to the Commission and from meetings it attended around the country that 'participation' was in danger of becoming a dirty word for people with experience of 'token' or 'window-dressing' participation or of superficial 
consultation exercises, limited to impenetrable questionnaires from which they had seen no positive outcomes or even feedback. Many felt exploited rather than empowered by what went for participation. Nevertheless, the demand for genuine participation was strong among some groups, despite the many barriers they faced.

These barriers are multiple and inter-connected. Some derive from poverty itself such as the struggle for day-to-day survival, which can sap people's energy and health; the inability to meet the financial costs that can be involved; lacking suitable clothes; feelings of stigma. These overlap with personal barriers, such as lack of self-esteem and self-confidence, which may derive in part from limited educational opportunities. Additional barriers can be faced by some groups, such as young people, disabled people, travellers, Asian women, asylum-seekers.

More institutional barriers include: lacking 'the tools of the trade' that professionals take for granted such as faxes, computers and internet access; the operation of social security rules that inhibit involvement for fear of affecting benefit entitlement; officials who use jargonistic language and who either resist participation or who engage in it in ways which are exclusionary.

In addition to barriers to participation, there are problems that can arise for which there is no easy solution. These reflect some of the more theoretical points made earlier. Examples are: how to engage the most marginalised people and ensure that minority views are heard and not drowned out by the loudest voices (this may include people who do not wish to identify themselves as 'poor'); and how to deal with arguments that, unless people have been elected, they are not 'representative' of people in poverty or have no right to speak on behalf of others? One Commission member suggested that instead of 'representatives' we should think of 'connectors' - people who help to connect marginalised groups to decision-makers and vice versa.

The Commission's Report draws on principles of empowerment, democracy, human rights and respect as outlined in the first part of this article. It argues that if people experiencing poverty were fully involved in decision making and policy processes, as we propose, we believe we would succeed in creating a new form of knowledge and a different kind of democracy' (CPPP, 2000: 49). It outlines a number of principles of participation and suggests ground rules for engagement as well as putting forward recommendations directed at national and local government and the devolved administrations.

Some parts of the Government are more open than others to the Commission's message. New Labour has accepted and promotes the message of participation at local neighbourhood level (Social Exclusion Unit, 2000, 2001). The case has also been accepted in a development context. DfID has observed that 'a human rights perspective on participation means moving beyond and above local-level processes of consultation through to ensuring poor people's participation in broader formal and informal systems of decision making' (DfID, 2000: 19). What is significant here is not simply the strong endorsement of participation but the explicit acceptance that it should not be confined to the local level.

The case for involvement of people in poverty in decisions taken at national level has not, however, yet been accepted in the domestic context (outside Scotland where there has been progress), although there have been some examples of national consultation exercises. Yet this is the level at which some of the most important decisions affecting people in poverty are taken. There is little or no acknowledgement 
that the particular expertise of those with experience of poverty could inform and thereby improve policy-making. Likewise, the principle of user-involvement, which is accepted in the sphere of welfare services, is not extended to benefits, despite the Green Paper on welfare reform's invocation of 'the rise of the demanding, sceptical, citizen-consumer' (DSS, 1998: 16; for a positive assessment of its potential see Stafford, 1997).

\section{Conclusion}

This article has attempted to chart, both theoretically and empirically, an approach to anti-poverty action, which is part and parcel of the democratic process and which represents both expression and recognition of the citizenship of those experiencing poverty. Although the article's focus has been on the process rather than the substance and outcomes of anti-poverty action, the latter, of course, must not be forgotten. Ultimately at issue, as hinted at earlier, are not just the promotion of genuine participation, but also the eradication of poverty and the redistribution of power.

\section{Notes}

1 Elsewhere, Fiona Williams (2000) also uses the notion of 'recognition and respect', with regard to a set of welfare principles.

2 This is just one example of what the North can learn from the South about participation; see also Hilary Wainwright's discussion of participatory local government budget decisions in Brazil (Guardian, 21 June 2000).

\section{References}

APPG on Poverty (1999), Policy, Poverty and Participation, London: APPG.

ATD Fourth World (1996), Talk with us, not at us, London: ATD Fourth World.

ATD Fourth World (1999), Influencing Policy in Partnership with the Poorest, London: ATD Fourth World.

ATD Fourth World (2000), Participation Works, London: ATD Fourth World.

Beresford, P. and Croft, S. (1995), 'It's our problem too', Critical Social Policy, 15: 2/3, 75-95.

Beresford, P., Green, D., Lister, R., and Woodard, K. (1999), Poverty First Hand, London: CPAG.

Berghman, J. (1995), 'Social exclusion in Europe', in G. Room (ed.), Beyond the Threshold, Bristol: Policy Press.

Blair, T. (1998), The Third Way, London: The Fabian Society.

Blair, T. (2001), 'Third way, phase two', Prospect, 10-13 March.

Bur A., Stevens, A., and Young L. (1999), Include Us In, Canterbury: European Institute for Social Services.

Byrne, D. (1999), Social Exclusion, Buckingham: Open University Press.

Clarke, M. and Stewart, J. (1998), Community Governance, Community Leadership and the New Local Government, York: Joseph Rowntree Foundation.

Commission on Poverty, Participation and Power (2000), Listen Hear. The Right to be Heard, Bristol: Policy Press/UK Coalition on Poverty.

Cornwall A. and Gaventa, J. (2000), 'Repositioning participation in social policy', IDS Bulletin, 31: 4, $50-62$.

Deacon, A. and Mann, K. (1999), 'Agency, modernity and social policy', Journal of Social Policy, 28: 3, 413-435.

Department for International Development (2000), Human Rights for Poor People, London: DfID. 
Ruth Lister

Department of Social Security (1998), New Ambitions for our Country, London: HMSO.

Donnison, D. (1998), Policies for a Just Society, Basingstoke: Macmillan.

Donnison, D. (2000), 'Equality: the new paradigm', Social Policy Association News, February/March, $25-6$.

Fraser, N. (1995), 'From redistribution to recognition?' ', New Left Review, 212, 68-93.

Fraser, N. (1996), 'Equality, difference and radical democracy', in D. Trend (ed.), Radical Democracy, New York: Routledge.

Fraser, N. (1997), Justice Interruptus, New York and London: Routledge.

Fraser, N. (2000), 'Rethinking recognition', New Left Review, 3, 107-120.

Galbraith, J. K. (1992), The Culture of Contentment, London: Sinclair Stevenson.

Galbraith, J. K. (1996), The Good Society, London: Sinclair-Stevenson.

Giddens, A. (1991), Modernity and Self-Identity, Cambridge: Polity Press.

Giddens, A. (1998), The Third Way, Cambridge: Polity Press.

Giddens, A. (2000), The Third Way and its Critics, Cambridge: Polity Press.

Gould, C. (1988), Rethinking Democracy, Cambridge: Cambridge University Press.

Hartsock, N. (1985), Women, Sex and Power, Boston: Northeastern University Press.

Holman, B. (1998), Faith in the Poor, Oxford: Lion.

Janoski, T. (1998), Citizenship and Civil Society, Cambridge: Cambridge University Press.

Levitas, R. (1998), The Inclusive Society?, Basingstoke: Macmillan.

Lister, R. (1997), Citizenship: Feminist Perspectives, Basingstoke: Macmillan.

Lister, R. and Beresford, P. (2000), 'Where are the poor in the future of poverty research?', in Bradshaw, J. and Sainsbury R. (eds), Researching Poverty, Aldershot: Ashgate.

Mayo, M. (2001), 'Community empowerment?', in New Challenges to Gender, Democracy, Welfare States, conference report, Denmark: GEP.

Mouffe, C. (1992), 'Feminism, citizenship and radical democratic politics', in J. Butler and J.W. Scott (eds), Feminists Theorize the Political, New York and London: Routledge.

Pateman, C. (1970), Participation and Democratic Theory, Cambridge: Cambridge University Press.

Phillips, A. (2001), 'Identity politics', in New Challenges to Gender, Democracy, Welfare States, conference report, Denmark: GEP.

Rinaldo Seitz, V. (1998), 'Class, gender and resistance in the Appalachian coalfields', in N. Naples (ed.), Community Activism and Feminist Politics, New York and London: Routledge.

Room, G. (1995), 'Poverty and social exclusion', in G. Room (ed.), Beyond the Threshold, Bristol: Policy Press.

Russell H. (ed.) (1996), Speaking from Experience, Manchester: Church Action on Poverty.

Social Exclusion Unit (2000), National Strategy for Neighbourhood Renewal, London: SEU.

Social Exclusion Unit (2001), A New Commitment to Neighbourhood Renewal, London: Cabinet Office.

Stafford, B. (1997), Partnership in Social Security, Loughborough: CRSP.

Taylor, C. (1992), 'The politics of recognition', in C. Taylor and A. Gutmann (eds), Multi-Culturalism and 'The Politics of Recognition', Princeton, NJ: Princeton University Press.

Trend, D. (ed.) (1996), Radical Democracy, New York: Routledge.

UNDP (1997), Human Development Report 1997, Oxford: Oxford University Press.

UNDP (2000), Human Development Report 2000, Oxford: Oxford University Press.

Williams, F. (1999), 'Good enough principles for welfare', Journal of Social Policy, 28, 4, 667-687.

Williams, F. (2000), 'Principles of recognition and respect in welfare', in G. Lewis, S. Gewirtz and J. Clarke (eds), Rethinking Social Policy, London: Sage.

Wilson R. (1995), Social Exclusion, Social Inclusion, Belfast: Democratic Dialogue.

Yeatman, A. (1994), Post-modern Revisionings of the Political, London: Routledge.

Young, I.M. (1990), Justice and the Politics of Difference, Oxford: Princeton University Press.

Young, I.M. (1997), 'Unruly categories: a critique of Nancy Fraser's dual systems theory', New Left Review, 222, 147-160.

Young, I.M. (2000), Inclusion and Democracy, Oxford: Oxford University Press. 